\title{
Re-Examining the Impact of Credit Risk on Profitability of Banks:Panel Evidence from Ghana
}

\author{
Evans Opoku-Mensah ${ }^{1} \quad$ Jemimah Hanna Nyakum $^{1} \quad$ Lydia NyankomTakyi $^{2} \quad$ Sandra Asantewa Ampofo ${ }^{1}$ \\ 1.School of Management and Economics, University of Electronic Science and Technology of China (UESTC) \\ 2.University of Education, Winneba-Kumasi Campus
}

\begin{abstract}
Credit risk management has become an instrument for the survival and growth of financial institutions. The major cause of banking problems has been identified as ineffective credit risk management. The Ghanaian banking sector is currently undergoing significant reforms which have led to some banks being collapse whiles others consolidated. This study seeks to re-examine the impact of credit risk on the profitability of Banks in Ghana. Panel data covering the period of 2010-2015 was gathered from 20 banks. Three determinants of credit risk were selected. These are asset quality, non-performing loan, and liquidity. Return on Asset (ROA) was employed as a measure of profitability. We found that that while the relationship between asset quality, non-performing loan and profitability were statistically significant, the relationship between liquidity ratio and banks' profitability was found to be insignificant. This shows that banks with huge non- performing loans are less profitable and prone to a high rate solvency rate. Based on the result of the study, it is recommended that banks should adopt and implement effective credit risk management strategies as it will enhance their profitability.
\end{abstract}

Keywords: Asset Quality Credit risk, Ghana, Non- performing loans. Liquidity Risk.

DOI: $10.7176 / \mathrm{EJBM} / 11-5-03$

\section{Introduction}

The banking industry has been earmarked as a key pillar to the achievement of vision 2030(Munge, Rotich and Wamukoya, 2014). A long long-term strategy to achieve this is by increasing savings, encouragement of foreign direct investment (FDI) and safeguarding the economy from external shocks. Having a sound financial system is vital towards achieving this goal as its failure of the financial system can disrupt the economic development of the country (Das and Ghosh, 2007). The major cause of banking problems has been identified as ineffective credit risk management(Koju, Koju and Wang, 2018). For a healthy banking sector, proper credit control measures should be in place. Credit risk is the likelihood of default by the borrower or counterparty such that loans, bonds or leases will not be repaid in time / in full, or the counterparty will fail to perform an obligation to the institution(Basle Committee on Banking Supervision, 2017).

Credit risk management has become an instrument for the survival and growth of financial institutions (Afriyie and Akotey, 2013). A strong credit risk management avoids drawbacks like credit concentrations, lack of credit discipline, aggressive underwriting to high-risk counterparts and products at inadequate prices. Proper credit risk management is likely to reduce the default rate of customers and minimize the complexities involved in planning, executing and controlling the overall running of a firm. The findings from (Athanasoglou, Delis and Staikouras, 2006) suggests that effective management of risk by banks has pervasive effects on their profits. Another study by (Bobakovia, 2003) also asserts that the profitability of a bank depends on its ability to foresee, avoid and monitor risk. Previous works that studied credit risk have found both positive(Hosna, Manzura and Juanjuan, 2009; Boahene, Dasah and Agyei, 2012; Saeed and Zahid, 2016) and negative relationships(Akhtar, Ali and Sadaqat, 2011; Kapur and Gualu, 2011; Khalid, 2012; Nchor and Darkwah, 2015).Despite the advantages associated with proper risk management, Ghanaian banks continue to record high non-performing loans(BOG, 2017).

The Ghanaian banking sector is currently undergoing significant reforms including compliance with the GH 400 million minimum capital paid up by December 31, 2018. In addition, all banks are expected to be Basel II/III compliant by the end of 2018. In comparison with 2016, the pace of growth in the industry's total assets, both domestic and foreign, moderated. The banking sector's total assets decreased from 28.1\% in December 2016 to $14.8 \%$ (year-on-year) as at end-December 2017(Bank of Ghana, 2018). Currently, the banking sector is experiencing panic withdrawals as depositors keep trooping to various banking halls to request for their money. This study re-examines the impact of credit risk on the profitability of Banks in Ghana. Panel data covering the period of 2010-2015 were collected from 20 banks for the analysis using the fixed effect regression model. Three determinants of credit risk were chosen in accordance with relevant literature. These are asset quality, nonperforming loan (NPL), and liquidity. Findings of the study contribute to theory by explaining the relationship between credit risk and banks' performance. This is of importance to policy makers who seek to develop policies for the sustained banking sector. This understanding helps investors and businesses who want to invest in profitable ventures for superior risk-adjusted returns in the financial sector. 


\section{Literature review, hypothesis and conceptual framework}

\subsection{Literature review}

Empirical evidence and the results of various studies show a mixed trend on the effect of credit risk on bank performance. Focusing on developed economies, a study by (Saeed and Zahid, 2016) examined the impact of credit risk on the profitability of UK firms for a period of 2007 to 2015 and found that NPL has a positive relationship with profit. Another study by (Ozili, 2017) found that NPLs are positively associated with banking crises and bank concentration. Contrary to the positive relationship findings, (Selma Messai and Jouini, 2013) focusing on Italy, Greece and Spain for the period of 2004-2008 found that default loans vary negatively with the profitability of banks. Confirming this results, (Hosna, Manzura and Juanjuan, 2009) found that NPL loan and capital adequacy ratios have an inverse relationship for banks in Sweden but the degrees of negative relationship differs from one bank to the other.

The literature on developing and emerging economies have also found both positive and negative relationship. A study by (Ogilo, 2012) found that capital adequacy, asset quality, management efficiency and liquidity have a weak relationship with financial performance (ROE) whereas earnings have a strong relationship with financial performance.(Kapur and Gualu, 2011) also found a negative impact of the non-performing loan on Ethiopian banks profit. Another study using Conventional Banks in Pakistan found that NPL ratio has a negative and significant effect on the profitability of banks (Akhtar, Ali and Sadaqat, 2011). In examining the relationship between asset quality and operating performance of Indian private commercial banking industry, (Khalid, 2012) found that asset quality and profitability are negatively related. Contrary to the negative findings (Afriyie and Akotey, 2013) found a significant positive relationship between non-performing loans and Ghanaian rural banks' profitability for the period between 2006 and 2010 and argued that despite higher loan losses, Ghanaian banks still earn a profit. Another work focusing on Ghana and using data from Ghana, (Boahene, Dasah and Agyei, 2012) argued that there is an effect of credit risk management on profitability level of Ghanaian banks and non- performing loans and profitability have a positive relationship. This according to them is attributed to high lending fees and commission charged. Confirming these results, (Ogboi and Unuafe, 2013)found that sound credit risk management, capital adequacy have a positive relationship with the Nigerian bank's financial performance. Studying 15 year period from 1997-201, (Onyekachi and Okoye, 2013) explained that the positive findings between NPL and banks performance are an indication that increase in loan and advances increases banks performance through interest income generated from loan and advance.

The literature surveyed reveals that numerous studies have studied different aspects of credit risk in both developed and developing economies and have found contradictory findings in both aspects. These contradictory conclusions emerging from the empirical literature is the motivation for the present investigation. Previous work from Ghana also shows both negative and positive findings. We investigate the impact of credit risk on banks profit for the period 2010-2015. This study is the first to examine the post global economic crises effect of nonperforming loans on banks performance. Again, the period under study includes the time when the Ghanaian economy was facing huge energy crises. Moreover, re-investigating this relationship will give more insight into factors that might have contributed to recent merging of 5 banks into one in Ghana.

\subsection{Conceptual Framework and hypothesis}

In line with the discussions above and the prevailing situations in Ghana, we pose that:

H1- Non-performing loans have a negative impact on the profitability of banks in Ghana.

$\mathrm{H} 2$ - Asset quality has a negative impact on the ROE of banks in Ghana

H3- Liquidity risk has a negative impact on the ROE of banks in Ghana.

The objective of this study is to examine the impact of the credit risk of banks on profitability in Ghana. Based on the study objective, a conceptual model is framed is framed to summarize the main focus and scope of this study in terms of variables employed. 
IISE

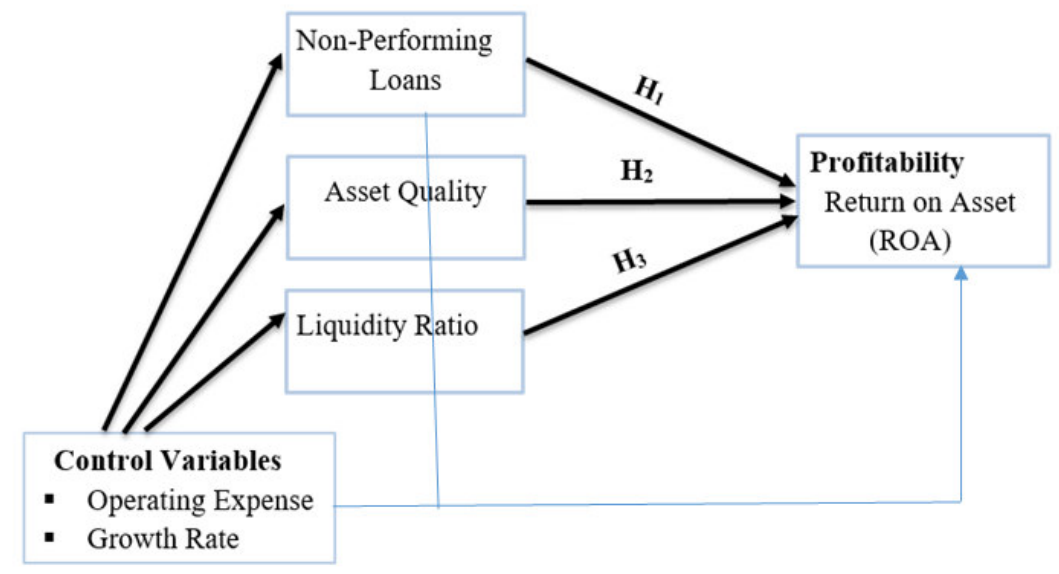

Figure 1- Conceptual framework

\section{Methodology}

We considered three major indicators of credit risk. These are asset quality, non-performing loans and liquidity ratio. Return on assets measures how efficiently a company can manage its resources(Ozili, 2017). While the focus is on credit risk, firm specific variables are used as control variables. Firm specific variables such as growth ratio and operating cost ratio are used as the firm's proxy. Data is obtained from the audited financial statement between the periods 2010 to 2015. Our sample is 20 out of the 29 Banks in Ghana. Purposive sampling was used to select the 20 banks because they have complete and the required data needed for this study. Table 1 presents the summary of variables.

Table 1 Summary of Variable

\begin{tabular}{|c|c|c|c|c|}
\hline & Variable & Symbol & Measurement & Source of Variable \\
\hline \multirow[t]{3}{*}{ Credit Risk } & $\begin{array}{c}\text { Asset Quality } \\
\text { Ratio }\end{array}$ & AQR & $\begin{array}{l}\text { The ratio of impairment } \\
\text { allowance to gross loan and } \\
\text { advances for bank } \mathrm{i} \text { in year } \mathrm{t}\end{array}$ & $\begin{array}{c}\text { Ghana banking } \\
\text { sector survey } 2016\end{array}$ \\
\hline & $\begin{array}{l}\text { Non- } \\
\text { Performing } \\
\text { Loans }\end{array}$ & NPLR & $\begin{array}{l}\text { The ratio of Impaired loans to } \\
\text { Total loan and advances for } \\
\text { bank } \mathrm{i} \text { in year } \mathrm{t}\end{array}$ & Bank of Ghana \\
\hline & $\begin{array}{l}\text { Liquidity Risk } \\
\text { Ratio }\end{array}$ & LRR & $\begin{array}{c}\text { The ratio of liquid funds to total } \\
\text { deposits for bank } i \text { in year } t\end{array}$ & PWC (2013) \\
\hline \multirow[t]{2}{*}{ Control Variables } & Growth Ratio & GWR & $\begin{array}{c}\text { Net interest margin = net } \\
\text { interest income / average } \\
\text { operating asset, year by year for } \\
\text { bank i in year } t\end{array}$ & PWC (2013) \\
\hline & $\begin{array}{c}\text { Operating Cost } \\
\text { Ratio }\end{array}$ & OCR & $\begin{array}{c}\text { The cost to income ratio = non- } \\
\text { interest operating expense / } \\
\text { operating income for bank i in } \\
\text { year } \mathrm{t}\end{array}$ & $\begin{array}{c}\text { Ghana banking } \\
\text { sector survey } 2016\end{array}$ \\
\hline Profitability & $\begin{array}{l}\text { Return on } \\
\text { Asset }\end{array}$ & $\mathrm{ROA}$ & $\begin{array}{l}\text { The ratio of profit after tax to } \\
\text { average total assets for bank i } \\
\text { and year } \mathrm{t}\end{array}$ & $\begin{array}{l}\text { the central bank's } \\
\text { Financial Stability } \\
\text { Report } \\
\text { (November 2015) }\end{array}$ \\
\hline
\end{tabular}

We estimated our regression equation by making ROA as our dependent variables and the three determinants of credit risk as independent variables. We regressed both dependent and independent variables together with other control variables as follows.

$$
R O A_{i t}=\beta_{0}+\beta_{1} N P L R_{i t}+\beta_{2} A Q R_{i t}+\beta_{3} L R_{i t}+\beta_{4} G W R_{i t}+\beta_{5} O C R_{i t}+\varepsilon_{i t}
$$

\section{Results and Discussions}

\subsection{Descriptive statistics}

Table 2 presents the descriptive statistics of the sampled firms. From the summary statistics, it can be observed that asset quality recorded an industrial average of $4.3 \%$. This means that on the average, the industry sets aside $4.3 \%$ of their total loans and advances as irrecoverable. Non-performing Loan has an industry average $4.10 \%$. This 
indicates that non- performing loan forms a lesser portion of the total loans and advances granted. Liquidity recorded a median value of $0.70 \%$. This is an indication that the banks under study, over the years are very liquid. Table 2 Descriptive Statistics of Study Variables

\begin{tabular}{|c|c|c|c|c|c|}
\hline Variables & Obs & Median & Std.Dev. & Min. & Max. \\
\hline ROA & 120 & 3.10 & 2.32 & -5.30 & 8.50 \\
\hline AQ & 120 & 4.30 & 5.43 & -1.10 & 25.50 \\
\hline NPL & 120 & 4.10 & 2.94 & 0.10 & 14.30 \\
\hline LR & 120 & 0.70 & 0.38 & 0.31 & 3.61 \\
\hline GW & 120 & 9.85 & 3.67 & 3.40 & 22.10 \\
\hline OC & 120 & 0.53 & 0.17 & 0.12 & 1.49 \\
\hline
\end{tabular}

\subsection{Correlation Matrix}

Table 3 shows the correlation matrix for the entire variables employed in the model. The coefficient of the correlation shows an index of the direction and the extent of the connection between two sets of the variable. The sign of the coefficient is a signal of the direction of the relationship while the absolute value of the coefficient indicates the magnitude. The result shows a lower correlation among all the variables with the exception of operating cost and return on an asset which is 0.84 . This is of the reason that, there exist similarity within the banks, with respect to their level of operating cost.

Table 3 Correlation Matrix of Panel Data

\begin{tabular}{|c|c|c|c|c|c|}
\hline & AQ & NPL & LR & GW & OC \\
\hline AQ & 1.000000 & -0.17466 & -0.13004 & 0.038153 & 0.170428 \\
\hline NPL & -0.17466 & 1.000000 & -0.36825 & 0.065111 & -0.07982 \\
\hline LR & -0.13004 & -0.36825 & 1.000000 & 0.179718 & -0.42679 \\
\hline GW & 0.038153 & 0.065111 & 0.179718 & 1.000000 & -0.40705 \\
\hline OC & 0.170428 & -0.07982 & -0.42679 & -0.40705 & 1.000000 \\
\hline
\end{tabular}

\subsection{Empirical Findings}

Table 4 presents the regression results. The R-squared from the result of the fixed effect shows that $88 \%$ of the systematic variation in the dependent variable (ROA) is explained by the five independent variables. The F-statistic value is significant at $1 \%$ level, which also indicates that there is a linear relationship between the five independent variables and returns on asset. From the result, asset quality and profitability are negatively related and statistically significant at $1 \%$ level. The beta coefficient indicates that a rise in the ratio of impairment allowance to gross loan and advances decreases return on assets by 0.082 The results further show that an increase in non-performing loan decreases returns on assets (profit) by 0.148 . Liquidity Risk although not significant, is also negatively related to profitability (ROA).In real figures any increase in the ratio of liquid funds to total deposit will result in 0.51 decrease in ROA. The results from the control variables show that whiles operating cost have an inverse relationship with ROA growth (11.54) we found that growth influence ROA positively. That is to say efficient management of bank operations although increases cost of operations enhances growth (Grygorenko, 2009).

Table 4 Effect of credit risk indicators on ROA

\begin{tabular}{|c|c|c|c|cc|}
\hline Variable & Coefficient & Std. Error & t-Statistic & Prob. \\
\hline AQ & -0.082203 & 0.019436 & -4.229500 & 0.0001 & $* * *$ \\
\hline NPL & -0.148758 & 0.071522 & -2.079879 & 0.0402 & $* *$ \\
\hline LR & -0.507962 & 0.369805 & -1.373593 & 0.1728 \\
\hline GW & 0.138174 & 0.035689 & 3.871565 & 0.0006 & $* * *$ \\
\hline OC & -11.54166 & 0.954267 & -12.09479 & 0.0000 & $* * *$ \\
\hline C & 9.476381 & 1.040751 & 9.105330 & 0.0000 & $* * *$ \\
\hline R-squared & & & & & \\
\hline Adjusted R-squared & 0.880353 & & & & \\
\hline F-statistic & 29.12508 & & & & \\
\hline Prob(F-statistic) & 0 & & & & \\
\hline Durbin-Watson stat & 1.827344 & & & & \\
\hline
\end{tabular}

$\mathrm{n}=180$, dependent variable: ROA, $* * *, * *, *$ significant level of $1 \%, 5 \%$ and $10 \%$ respectively.

\subsection{Discussion}

The negative significant relationship between asset quality, non-performing loans and ROA is an indication that both indicators are determinants of profit in Ghanaians banks' profits. This suggests that huge asset quality and non-performing loans reduce both loan amounts and interest income in Ghanaian banks. With a reduction in both 
loan advanced and interest earned, Ghanaian banks are not able to recoup amount given out as loan and are not able to earn profit thereby impacting banks profit negatively. In contrast to the work of (Boahene, Dasah and Agyei, 2012; Afriyie and Akotey, 2013)who found a positive relationship between credit risk and banks performance in Ghana, our results found a negative effect . The negative relationship is in consistence with earlier works (Kolapo, Ayeni and Oke, 2012; Saeed and Zahid, 2016). It is likely that the findings from previous works might have been affected by the period of their study. Previous works in Ghana studied period which included both pre and posts global economic crises.

The possible reason for this negative relationship could be due to both internal and external factors. First the depreciated cedi is likely to contribute to firms and individuals' inability to pay their loans. The Ghana cedi as against the dollar has experienced massive depreciation from GHC 1.43176 in January 2010 to GHC 3.80997 in December 2015(Trading Economics, 2018). With the depreciation of the Ghana cedi comes increases in prices of goods and services, bringing harsh economic conditions to both firms and individuals, making them unable to pay their loans. Another reason for the negative relation of the non-performing loan on profit could be the reaction of certain managers to competition. In order to survive in the Ghanaian finance sector, some managers of Ghanaian banks device strategies that encourage borrowing. These policies like higher interest rate increase the granting of credit facilities to marginal borrowers. Although this compromises lending standard, it delivers short-term results. The long run effects of this strategy are credit losses as in many cases most of these customers are unable to pay these loans.

Although the impact of liquidity risk on profitability was found to be insignificant, the inverse relationship depicts that liquidity risk contributes to a number of bank failures. The insignificant relationship may be explained by the omission of variables such as locations variables that could be added to make the relationship significant. It has been established that the bank's profitability can be determined by internal control and external control variables. The external determinants of banks' profitability encompass factors such as the economic environment. Interestingly, our time horizon for this study stretches the financial crisis period and the period where Ghanaian commercial banks were going under major transformation, which had a tremendous effect on the Ghanaian economy. During this period the system risk played a significant role in determining the profitability of banks which was uncontrollable by the visible hands. Hence, the ROA could be abnormally affected during this period. The negative relationship between asset quality and profit is in consistence with earlier works (Liyuqi, 2007; Cornett et al., 2011).

\section{Conclusion, implication and recommendation}

This study analyzed the impact of credit risk on the profitability of Ghanaian banks. The findings revealed that credit risk does have negative effects on the profitability of banks in Ghana. Between the proxies of credit risk and its control variables, asset quality, non-performing loans, operating cost, and growth did have a significant effect on profitability (ROA) while liquidity has an insignificant effect on ROA. Asset quality, non-performing loan, liquidity, and operating cost have a negative relation with profitability whiles growth has a positive relation. We found that non-performing loans play a major role in depleting profitability. NPL is a risk indicator which determines the quality of loans, hence banks with huge non- performing loans have poor asset quality and are less profitable.

Banks should tighten credit control policies. As credit has always been the core of banking operation, the focus of banks concerning risk has to be on managing credit risk. Better risk management indicates that banks operate at lower relative risk (efficiency in operation) and at the lower conflict of interests between parties. This will help in improving the liquidity of banks and hence increase its profit level. This is essential in ensuring sustainable profit in banks operations leading to the long-term success of any banking organization as well as the industry as a whole.

Again, banks should recruit better risk expertise. Experts in risk will ensure effective and efficient liquidity management. This will save banks from a liquidity crisis, improve the profitability and also enable the bank to cater to its short-term financial needs as and when it falls due. Moreover, since operating cost influences banks profit, a major component of operating cost such as salaries, occupancy cost, energy cost should be kept under control. When operating cost is high, it depletes banks profit. To achieve this, banks should train their staff to become professionals and specialized at their job so they do not incur the cost of employing specialist aside paying salaries to staff who could have been able to perform those functions if they were trained.

As part of measures to control default payment, it is recommended that there should be a proper database which will have details of credit worthiness of Ghanaian citizens. As it stands now, managers of banks are unable to determine the credit worthiness of customers. Managers give loans based on their own assertions and perceptions. Moreover, lack of good address and house numbering system also makes as it is difficult to trace people to their residences. With a proper database of customers credit worthiness, banks could easily know either to lend or otherwise to each borrower. Future works should investigate the effects of the panic withdrawal on the Ghanaian economy. 


\section{References}

Afriyie, H. O. and Akotey, J. O. (2013) 'Credit risk management and profitability of selected rural banks in Ghana.', Journal of Risk Finance, 4(2), pp. 1-18.

Akhtar, F. M., Ali, K. and Sadaqat, S. (2011) 'Factors influencing the profitability of conventional banks of pakistan', International Research Journal of Finance and Economics, (66), pp. 117-12.

Athanasoglou, P., Delis, M. and Staikouras, C. (2006) Determinant of banking profitability in the south eastern European region, The World Bank Economic Review Journal.

Bank of Ghana (2018) BANK OF GHANA Banking Sector Report.

Basle Committee on Banking Supervision (2017) Basel Committee on Banking Supervision Basel III: Finalising post-crisis reforms, Bank for International Settlements. doi: 10.1159/000365926.

Boahene, S. H., Dasah, J. and Agyei, S. K. (2012) 'Credit risk and profitability of selected banks in Ghana.', ResearchJournal of Finance and Accounting, 3(7), pp. 6-15.

Bobakovia, I. V (2003) Raising the profitability of commercial banks, BIATEC.

BOG (2017) Banking Sector Stability Report.

Cornett, M. M., McNutt, J. J., Strahan, P. E. and Tehranian, H. (2011) 'Liquidity risk management and credit supply in the financial crisis.', Journal of Financial Economics, 101(2), pp. 297-312.

Das, A. and Ghosh, S. (2007) 'Determinants of credit risk in Indian state-owned banks: an empirical investigation', Economic Issue-Stoke and Trent, 12(2), pp. 27-46.

Grygorenko, O. (2009) Effects of price setting on bank performance: the case of Ukraine. Kyiv, Ukraine.

Hosna, A., Manzura, B. and Juanjuan, S. (2009) Credit risk management and profitability in commercial banks in Sweden. University of Gothenburg.

Kapur, D. and Gualu, K. A. (2011) 'What drives the performance of commercial banks in Ethiopia?', International Journal of Research in Commerce \& Management, 2(7), pp. 1-11.

Khalid, A. (2012) 'The impact of asset quality on profitability of private banks in India: A case study of JK, ICICI, HDFC \& YES Banks.', African Macroeconomic Review, 2(1), pp. 2-16.

Koju, L., Koju, R. and Wang, S. (2018) 'Does Banking Management Affect Credit Risk? Evidence from the Indian Banking System', International Journal of Financial Studies, 6(3), p. 67. doi: 10.3390/ijfs6030067.

Kolapo, T. F., Ayeni, R. K. and Oke, M. . (2012) 'Credit risk and commercial banks' performance in Nigeria: a panel model approach', Australian Journal of Business and Management Research, 2(2), pp. 31-38.

Liyuqi (2007) "Determinants of Banks profitability and its implication on Risk management practices: Panel Evidence from the Uk. University of Nothingham.

Munge, E., Rotich, D. C. and Wamukoya, J. (2014) 'A situational analysis of information management in selected government ministries in the context of Kenya Vision 2030', African Journal of Library Archives and Information Science, 24(1), pp. 15-26.

Nchor, D. and Darkwah, S. A. (2015) 'Inflation, exchange rates and interest rates in Ghana: An autoregressive distributed lag model', Acta Universitatis Agriculturae et Silviculturae Mendelianae Brunensis, 63(3), pp. 969-977. doi: 10.11118/actaun201563030969.

Ogboi, C. and Unuafe, O. K. (2013) 'Impact of Credit Risk Management and Capital Adequacy on the Financial Performance of Commercial Banks in Nigeria', Journal of Emerging Issues in Economics, Finance and Banking (JEIEFB), 2(3), pp. 703-717. doi: http://dx.doi.org/10.4322/natcon.2012.019 Species.

Ogilo, F. (2012) 'The Impact of Credit Risk Management on Financial P erformance of Commercial Banks in Kenya', DBA Africa Management Review, 3(1), pp. 22-37. doi: DOI 10.1016/j.enggeo.2011.05.015.

Onyekachi, E. and Okoye, V. (2013) 'Impact of corporate social responsibility on the deposit money banks in Nigeria', Global Business and Economics Research Journal, 2(23), pp. 71-84. doi: 10.5296/ijld.v2i6.2717.

Ozili, P. K. (2017) Non-Performing Loans and Financial Development: New Evidence, SSRN. doi: $10.2139 /$ ssrn.2892911.

Saeed, M. S. and Zahid, N. (2016) 'The impact of credit risk on profitability of the commercial banks.', Journal of Business and Financial Affairs, 5(2).

Selma Messai, A. and Jouini, F. (2013) 'Micro and Macro Determinants of Non-performing Loans', International Journal of Economics and Financial Issues, 3(4), pp. 852-860. doi: 10.1300/J079v27n04_02.

Trading Economics (2018) 'Ghanaian Cedi'. Available at: https://radingeconomics.com/ghana/currency. 